\title{
Home Finance - The Source of Improving Wellness of the Population
}

\author{
Xodjimuhamedova Shokhida Ibragimovna, Tolipova Dilfuza Nabievna, Tashkhodzheva Gulnoza \\ Saydamhodzhaevna, Akramova Nargiza Ahrorovna, Shafkarov Fakhriddin Xudayberdiyevich, \\ Bobonarova Kamola $\mathrm{O}^{`}$ kamjon qizi
}

\begin{abstract}
For a qualitative analysis of the state of modern society and financial relations prevailing in the financial system of our country, it is especially important to study issues related to attracting public finances to the state economy.

The long process of developing commodity-money relations has radically changed the content of finance. If earlier in these relations the main and fundamental role was played by the monarchs, the state, as the owners of all property, then in the $X X$ century. The main owners of valuables, including enterprises and firms, are citizens, and the state represented by public authorities acts as an intermediary and a consumer of redistributed wealth.

Confirming this thesis, $P$. Drucker expressed that the main impetus of progress now comes not from the social structure, but from an individual, and the present time requires every person to take effective actions to transform not only society, but above all himself [1].
\end{abstract}

\section{INTRODUCTION}

In economic theory ("mainstream"), households and firms are mainly taken as the basic elements, but these days it is increasingly argued that these elements are in turn constructed from separate components. The structure of the explanation has a pyramid shape. In addition, each element rests on the other, lying below it.

For too long, economists have seen in households and firms unitary decision-making elements as if they were single subjects and ignored such real individuals involved in this process as employees of a company or women in a household [2].

In the structure of monetary and financial relations arising within the household, there are not only family finances, which characterize the economic relations between spouses, but also personal finances-finances of individual family members.

The economic behavior of subjects in the context of market relations emphasizes that their individual financial decisions are characterized by their own private interests, which are primarily beneficial to themselves. But the existing market with imperfect competition also forces its participants to adapt to each other, forcing them to make

Revised Manuscript Received on July 18, 2019

Xodjimuhamedova Shokhida Ibragimovna, Assistant Professor, Tashkent Institute of Irrigation And Agricultural Mechanization Engineers

Tolipova Dilfuza Nabievna, Senior teacher, Tashkent Institute of Irrigation And Agricultural Mechanization Engineers

Tashkhodzheva Gulnoza Saydamhodzhaevna, Assistant, Tashkent Institute of Irrigation And Agricultural Mechanization Engineers

Akramova Nargiza Ahrorovna, Assistant, Tashkent Institute of Irrigation And Agricultural Mechanization Engineers

Shafkarov Fakhriddin Xudayberdiyevich, Assistant, Tashkent Institute of Irrigation And Agricultural Mechanization Engineers

Bobonarova Kamola O'kamjon qizi, Student, Tashkent Institute of Irrigation And Agricultural Mechanization Engineers compromise financial decisions that satisfy the economic interests of the parties.

At the same time, the role of the financial mechanism is exercised by the personal finances of individuals who ensure the balance of the economic decisions made by business entities.

In forming the economic relations arising between the elements of the state's financial system, it is necessary to take into account the fact that economic relations established in society, based solely on the priority of personal interests and the denial of public interests, cannot but divide them into separate economic entities, including domestic ones. households whose main goal is to improve personal wellbeing, rather than the welfare of society.

At the same time, it should not be forgotten that the main task of society is to improve the well-being of the population, is to build an effective and promising system of economic relations based on market principles aimed at creating personal citizens' finances and ways to manage them.

Recently, various terms have appeared in the scientific literature to describe the finances of the population as part of the country's financial system: "household finances", "household finances and social sphere", "personal finances", "personal finances", "citizens finances", "finances citizens and families "," individuals' finances "," consumer finances "," finances of the consumer sector "," financial flows of the consumer market of the population ", etc.

The increase in the number of publications devoted to the study of the structure of public finances is not accidental, and this is explained by the fact that the amounts of financial resources held by individuals are comparable with the size of foreign borrowings of the state.

This is due to the fact that currently $50-60 \%$ of the national wealth and $70-89 \%$ of the GNP (GENERAL NATIONAL PRODUCT) created are owned by individuals (citizens, employees and capital owners) [3].

V.A. Slepov, R.S. Ekshembiyev rightly point out that personal finance is the basis of the modern financial system of the state. They predetermine the capacity of the domestic market, the volume of resources of the budget system, the dynamics of the investment process, the standard of living. This is due to the fact that in a developed economy, individual incomes account for about $70 \%$ of GDP(GENERAL DOMESTIC PRODUCT). 
However, despite the enormous importance of social finance in the economy, the laws and factors of their formation, the relationship with corporate and public (state and municipal) finances, the impact on macroeconomic processes, management features [4] are not fully understood.

Individual policy in the formation of financial relations affects the definition of a person's success in life. For many people, success means high income and well-being, a way to achieve their goals, a wide choice of opportunities to meet their needs, etc.

At the level of individual motivation for increasing personal well-being, the increase in the dominant share of the financial component in the budget structure of a household or family has the combined effect of using personal finances as a constant desire of an individual to increase consumption and move up the social scale. Individual motivations in which decisions are made to acquire the appropriate type of goods and services, in addition to economic, depend on cultural, temporal and other variables.

Families, health, age, income, reference groups have a great influence on people's understanding of the problems of improving their financial well-being and how to solve them. As people go through different stages of life, their needs change in many ways. In addition, in anticipation of increasing incomes, consumer desires are increasing [5].

Within the boundaries of the household, the laws of the market do not explicitly apply, and in the first place are common family principles and values, but at the same time, the desire of individuals for personal financial independence from other family members will be decisive.

Inside the household, the individual directly sees in himself the true, ultimate goal of self-reproduction as the meaning of realizing his own being, spreading this relationship to the world through his relatives and relatives.

The main task of the household finances is to maintain the existing family welfare, and this is not only the preservation of the existing level of income and "self-insurance" of property security, but also the formation of quality characteristics of consumption.

The basic principle of the formation of household finances is their focus on meeting the needs of both the whole family taken as a whole and the personal needs of each family member taken separately.

The family, as a whole, independently develops their preferences, i.e. ensuring the overall satisfaction of the needs of all family members should dominate the individual preferences of each.

\section{RESULTS \& DISCUSSIONS}

Regardless of what a family member acquires, he simultaneously uses several budgets (family and personal), which are spent to purchase goods and services.

If food products are for all family members, then in this case the general family budget will be used, which consists of the financial income of all family members, and if goods are purchased for personal, individual use, then the personal budget will be partially used. Therefore, all purchases made for a family (household) can be considered from the point of view of whether they have economic components that all family members will have to pay in the purchase process.

In this case, the individual independently determines the goals and objectives of his production activities for the formation of a personal budget. At the same time, the relationship of the personality of dependence, the personal interests of the individual is replaced by his dependence on the relationship that occurs inside the household, where the relations of people living together manifest themselves in economic relations. Thus, within each household, the personal dependency of family members on each other, children on parents, wife on husband, dependents on the breadwinner, and vice versa, prevails.

Relationships of personal dependence are manifested in the creation of living conditions, the provision of financial resources, necessary household items, food and industrial goods, i.e. relations of personal dependence are replaced by the material dependence of one family member on another. Throughout their lives, people constantly enter into relations related to production, distribution, 9. redistribution), exchange and consumption of material goods, both with individuals and with legal entities. And among them the main place is occupied by economic relations aimed at the formation of the individual economic status of the individual, which is the main personal wealth and behavior of the individual.

The desire of the individual to personal independence, and first of all material, leads to the creation of his personal finances, his personal budget management, the formation of personal well-being, the development of individuality.

Economic relations arising between family members are manifested as economic interests, which to a greater or lesser extent are expressed through a system of relationships aimed at creating personal well-being within the household.

In order to achieve financial well-being, a structured and integrated approach to a balanced family (personal) budget management strategy, defining tactics of setting goals for improving the financial situation, primarily personal, and implementing directions and methods of forming family (personal) finances are needed.

In the formation and management of personal finance, there are many aspects that the individual does not usually think about.

In order for an individual to rise to a higher social level, a different order of personal finances is needed, higher than the one he had before.

The problem of the financial independence of family members to appear in the formation of the family budget, the organization of methods of housekeeping and the allocation of the right to control general finances.

The general principle of justice (to each his own) as applied to the exchange of resources (financial, labor, etc.) within the household can be formulated as follows: for everyone, what is due to him in a competitive market, i.e. in case the economy conforms to its nature. 
A prerequisite for the prevalence of economic relations in existing relationships within the household is the personal financial dependence of people: in the form of dependence of each person not only on another, but also on finances brought by other people to the family. The main nit of measurement is money as the main motive for making certain financial decisions, expressing the power of those who have them over those who do not have them.

\section{CONCLUSION}

Thus, in the sphere of exchange, the principle of justice "to each his own" takes the form of equivalence of exchange, which in turn manifests itself in the equality of the market value of a product or service and its monetary price [6].

What exactly will go to each participant in the family economy as a result of economic activity is determined by the form of financial relations that have developed in the household.

Each family member independently participates in building a family economy for personal gain, separating their personal property from family-wide and achieving their own goals, primarily economic ones, which may not coincide with the general principles of running a household.

With the common goal of contributing to the maintenance of the general budget of the family in which he lives, personal benefit comes to the fore in the formation of his own, independent personal finances, which an individual can dispose of individually.

J. Galbraith argued: "Economists have long argued unconditionally that no motive of human behavior can be compared in strength with the desire for personal gain ... The premise that people strive to maximize their income, that is, to to achieve the greatest monetary benefit for itself, is attractive by the absence of sentimentality "[7].

At the same time, it is necessary to master the main principle that personal finance is personal financial assets that can give financial independence are not created in one day. Great savings are created by labor, no matter what physical or mental, the right attitude to managing personal finances in the system of market relations.

The welfare of the family can not serve as a goal, but is only a concomitant attribute of the individual's activity. Personal finances, independent of family finances and your personal budget, which you yourself manage, is not an abstract category, but the ultimate goal of an individual's economic activity, aimed at meeting his personal needs.

But it can be a "guiding star" as long as the motivation for ensuring the well-being of your family becomes dominant compared to creating personal well-being.

The principle of comparative advantage suggests that each person must expend efforts in the area where they bring the greatest return, in other words, where the opportunity cost of his choice is minimal [8].

\section{REFERENCE}

1. Drucker, P. Management: Tasks? Responsibilities. Oxford: Blackwell. 1994. P. 102f.

2. Hojon Jeffery. Economic Theory and Institutions: The Manifesto of Modern Institutional Economic Theory / Trans. from English M .: Delo, 2003. p. 113.
3. Fetisov V. D. Finance and credit: Textbook. / V.D. Fetisov, T.V. Fetisov. - 2nd ed., Pererab. and add. M .: UNITIDANA, 2006. P. 157.

4. Slepov V. A., Ekshembiyev R. S. Personal Finance // Finance and Credit. 2007. No. 40 (280). S. 2.

5. Finance: Textbook / Ed. S.I. Lushin, V.A. Slepova.- 2nd ed., Pererab. and add. M .: Economist, 2003. p. 461.

6. Kozlowski P. Principles of ethical economy. - SPb .: School of Economics, 1999. p. 240.

7. Galbraith J. New Industrial Society. M .: Progress, 1996. P. 159160.

8. Martsinkevich V.I. Economics of Man. Training allowance / Martsinkevich V. I., Sobolev I. V. Moscow: Aspect Press, 1995. P. 151. 